\title{
Characterization of Solid Wastes from Aluminum Tertiary Sector: The Current State of Spanish Industry
}

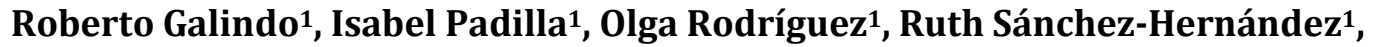 \\ Sol López-Andrés ${ }^{2}$, Aurora López-Delgado ${ }^{1}$ \\ ${ }^{1}$ National Centre for Metallurgical Research, CENIM-CSIC, Madrid, Spain \\ ${ }^{2}$ Department of Crystallography and Mineralogy, Faculty of Geology, UCM, Madrid, Spain \\ Email: alopezdelgado@cenim.csic.es
}

Received 9 February 2015; accepted 27 February 2015; published 4 March 2015

Copyright (C) 2015 by authors and Scientific Research Publishing Inc.

This work is licensed under the Creative Commons Attribution International License (CC BY). http://creativecommons.org/licenses/by/4.0/

c) (i) Open Access

\begin{abstract}
Aluminum recycling is an important activity that allows returning this metal to the market saving energy and resources. This activity generates slag and dross, both hazardous materials, which are recovered by other industries (tertiary sector). In that process, new wastes are produced, but most of them are disposed in security storage facilities because of their hazardousness and scarce marketable value. In Spain, the statistical data analysis on waste reveals that this sector is increasing every year. This study aims to characterize the wastes generated by the tertiary aluminum industries in Spain. Samples were collected in different aluminum recycling industries and characterized by chemical analyses, $X$-ray fluorescence, $X$-ray diffraction and particle size determination. Wastes rich in aluminum oxide and alkaline elements also comprise metallic aluminum and aluminum nitride. Such components are the main responsible for the waste hazardousness since they generate toxic gases in the presence of water. Besides, their fine granulometry $\left(x_{50}<30\right.$ $\mu \mathrm{m})$ also contributes highly to the hazardousness.
\end{abstract}

\section{Keywords}

Hazardous Aluminum Waste, Characterization, Recycling, Slag/Dross

\section{Introduction}

Aluminum is a product with growing consumption in most areas of everyday life such as transport, engineering, construction and packaging, due to its remarkable properties. The worldwide implementation of aluminum has 
been successful due to the cost reduction in manufacturing process and the huge possibilities of recovery. The Life Cycle Assessment (LCA) of aluminum is composed of several activities (industries) which form a loop that allows minor costs in market. The LCA of aluminum in 2010 revealed that around $50 \%$ of total ingot production was produced from secondary aluminum industry generated in Spain, and around 20\% from secondary aluminum imported [1].

The primary production is focused on obtaining the aluminum from bauxite, an expensive activity due to its high energy consumption. This metal is sold to smelters that transform these ingots into sheets, foil or profiles (semi-production). The secondary aluminum industry is based on end-of-life products (scrap), slag and skimming from primary industry and semi-production. This industry smelts wastes and inserts them again into the semi-production chain. And finally, wastes from previous businesses (especially slag or dross) are recycled by the tertiary aluminum industry, which uses different processes to recover the residual aluminum present in this kind of waste materials.

The aluminum recycling process has been already detailed by Tsakiridis [2], who also described the characterization and utilization of aluminum salt slag. The conventional process used in this industry consists of grinding the slag or dross and sieving it to recover the metal [3]. Several fractions are separated according to their granulometry. The coarsest fractions are sold to other industries because of their high aluminum content. However, the finest fraction, captured by suction systems and treated in sleeve filters, is not a marketable product due to its lower aluminum content. Accordingly, it is the main waste generated by the tertiary industry [4].

After the grinding and sieving treatment, a water leaching process is also commonly used to separate aluminum from the non metallic material as well as to dissolve the salts present in the dross [3]. The reaction of some components present in dross with water, such as aluminum nitride, aluminum carbide and metallic aluminum, leads to release toxic gases, namely ammonia, methane and hydrogen, and thus causing new compounds in the solid waste as aluminum hydroxides [5]-[7]. As a consequence of this recycling process, a low aluminum recovered/waste treated rate is obtained.

Due to the huge and growing demand for aluminum around the world, significant quantities of wastes are still generated despite the optimization of recycling, and specific control measurements are required, especially for the hazardous wastes.

There is no precise information about the benefit of using dry or wet techniques in the processes used by the tertiary industry for slag recycling. Neither are available exact data on the residues generated by tertiary industries. Accordingly, the characterization of these materials is an important tool to develop their best treatment and disposal pathway. In this sense, there are few examples of characterization of these powders from tertiary industry which can content several components in such heterogeneous mixture, such as corundum, spinel, aluminum nitride, metallic aluminum, quartz, calcite, iron oxide, etc. [8].

So, the aim of this work is to characterize samples of fine solid waste generated by tertiary industry in Spain, to acquire a better understanding about this particular hazardous waste, by means of its composition (chemical and mineralogical) and particle size.

\section{Current State}

\subsection{The Aluminum Recycling Industry in Spain}

Spain has a large industrial aluminum sector, but very fragmented in many medium and small companies. Industries include primary production (being the third largest producer in Europe with $17 \%$ of total production in 2012) [9] as well as secondary production (more than $35 \%$ of total aluminum production), and waste recycling, where the best available techniques (BAT) for the non-ferrous metal industries are applied [10] [11]. The main industrial areas that perform the recovery and disposal of hazardous wastes from aluminum industry are mainly located in the north and centre of Spain, which are traditional areas of the metallurgical activities. Figure 1 indicates the main industrial sites where recovering and disposal activities are performed for hazardous wastes from aluminum industry in Spain (wastes are identified by the European Waste Catalogue (EWC) code, Table 1).

\subsection{Legal Framework for Hazardous Wastes in the Aluminum Industry}

The Spanish legal framework for hazardous wastes is based on the transposition of the Directive 2008/98/EC of the European Parliament on waste which indicates the following waste hierarchy: prevention, preparing for re- 


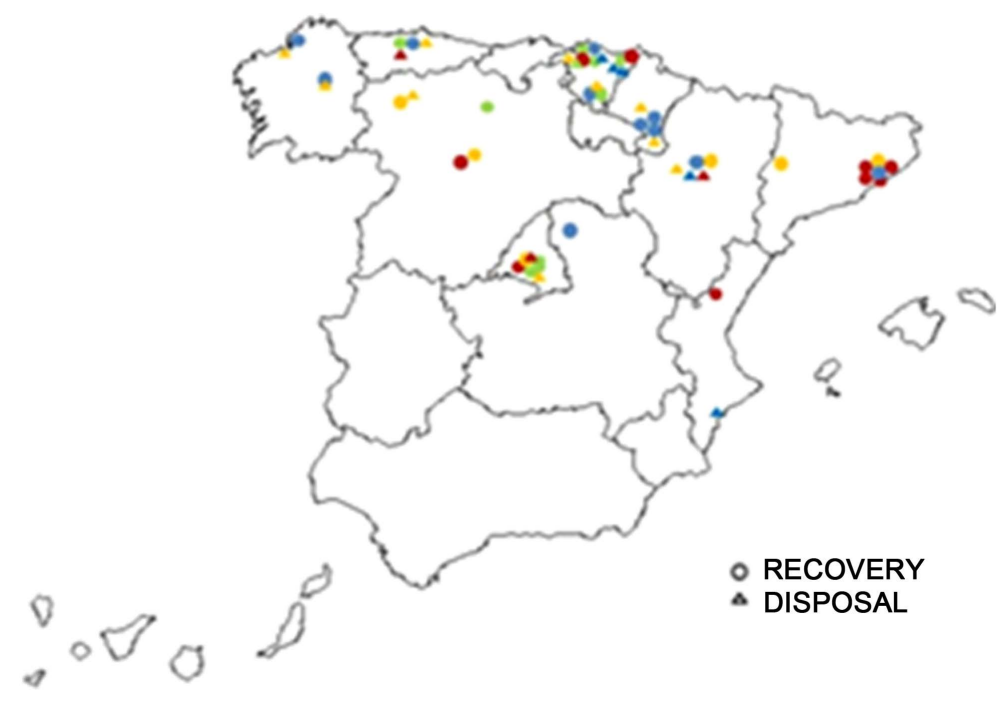

Figure 1. Main Spanish industrial sites for aluminum production where hazardous waste treatment is performed (wastes with EWC code: $100304=$; $100308=$ 口 $; 100309=\quad ; 100321=$ ).

Table 1. European Waste Catalogue (EWC) for hazardous in the aluminum thermal metallurgy.

\begin{tabular}{cc}
\hline EWC & Hazardous waste \\
100304 & Primary production slag \\
100308 & Salt slag from secondary production \\
100309 & Black dross from secondary production \\
100315 & Skimming that are flammable or emit, upon contact with water, flammable gases in dangerous quantities \\
100317 & Tar-containing wastes from anode manufacture \\
100319 & Flue-gas dust containing dangerous substances \\
100321 & Other particulates and dust (including ball-mill dust) containing dangerous substances \\
100323 & Solid wastes from gas treatment containing dangerous substances \\
100325 & Sludge and filter cakes from gas treatment containing dangerous substances \\
100327 & Wastes from cooling-water treatment containing oil \\
100329 & Waste from treatment of salt slag and black dross containing dangerous substances \\
\hline
\end{tabular}

use, recycling, other recovery and disposal. Furthermore, these wastes are classified according to the European Waste Catalogue (EWC) (Table 1) as the Spanish regulation, MAM/304/2002, indicates [12].

The Spanish Register of Emissions and Pollutant Source [13] provides information of hazardous wastes transfer for both recovery and disposal activities, being a useful source of the quantity of wastes generated by aluminum industries, due to the strong fragmentation and the lack of information provided by other sources or references. According to this register, the majority of hazardous wastes, in terms of transfer tons, are represented by the primary smelting slag (EWC 100304), salt slag from secondary smelting (EWC 100308), black dross from secondary smelting (EWC 100309) and other particulates and dust (including ball mill dust) containing hazardous substances (EWC 100321).

The evolution of total waste transfer (disposal and recovery) in tons per year during the period 2007-2012 in Spain has varied according to aluminum industry demand (Figure 2).

As can be seen, primary smelting slag and salt slag from secondary production amounted to more than 100,000 tons per year. In general, from 2007 to 2009 there was a drop in the primary slag and salt slag transfer, 


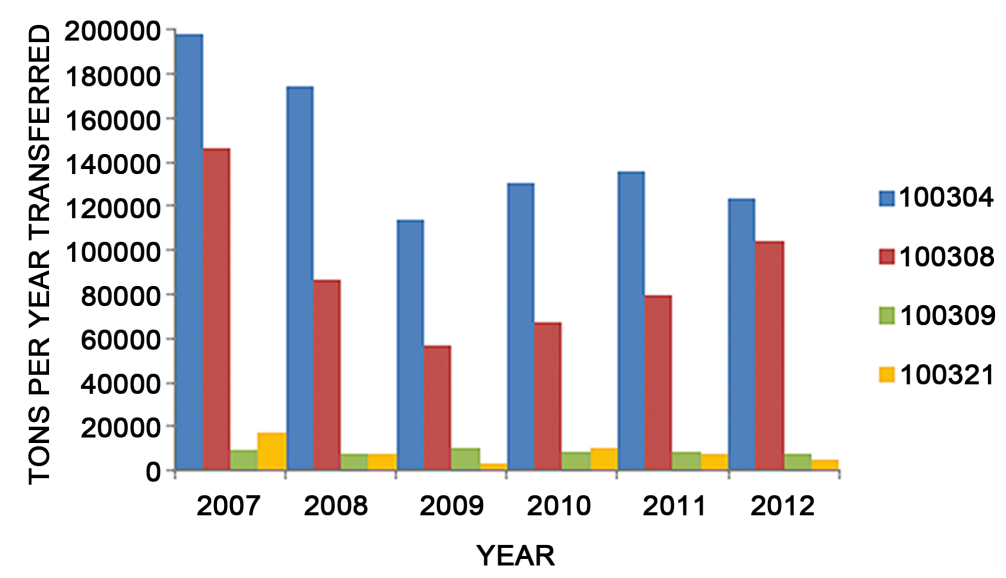

Figure 2. Total tons per year transferred by the main hazardous wastes in the aluminum industry in Spain. 100304: primary smelting slag; 100308: secondary smelting salt slag; 100309: secondary smelting black dross; 100321: particulates and dust, including ball mill dust (Official statistical data compiled from [13]).

while from 2010 onwards a slight increase occurred in this transfer as well as in the aluminum manufacturing, showing the corresponding rise in the waste transfer. In 2012, the secondary industry suffered a strong growth crisis in comparison to the primary industry. This fact was clearly reflected by the similar quantities of waste transfer obtained. On the other hand, black dross from secondary smelting and other particulates (dust containing hazardous substances) were transferred less than 20,000 tons per year from secondary smelting.

Figure 3 shows the quantity of hazardous waste per tons and year transferred in Spain during the same period, 2007-2012. As shown, primary production slag (100304) presented low recovery rates and its disposal into secure landfill was intense especially since 2009. On the other hand, salt slag smelting (100308) and black dross (100309) from secondary aluminum industry achieved high recovery rates over the period. In the case of other particulates (100321) recovery percentages were around 50\% referred to the total transfer.

Regarding the fine powder coming from the bag filter suction systems used in the aluminum slag milling, it is considered as hazardous waste included in the EWC 100321 group. Nevertheless, this waste generated by the Spanish tertiary industry is not recovered. So, its disposal into secure landfill is the current option selected for its control, as a profitable recovery is not possible.

\section{Experimental}

Dried fine powder samples of a bulk of hazardous wastes from different Spanish tertiary aluminum industries were collected and kept into polyethylene bags. Samples come from the bag filter suction system of the aluminum slag milling process. Powders were labeled as Sx (x: 1 - 11). Next, bulk samples $(2 \mathrm{~kg})$ were divided into eight representative samples by a Laborette 27, rotary cone sample divider. Representative samples were characterized as follows: Determination of particle size distribution was carried out using a Sympatec Helos 12LA by ultrasonic dispersion in isopropyl alcohol. Sample composition analysis was performed by X-ray fluorescence (XRF), using a wavelength dispersive X-ray fluorescence spectrometer (Bruker, S8 Tiger), with rhodium anode and $4 \mathrm{~kW}$ excitation power. Measurements were done on fusion disks prepared with lithium tetraborate and lithium metaborate at $60 \mathrm{kV}$ and $170 \mathrm{~mA}$ tube setting and using crystals LiF (220), LiF (200), PET, and XS-55 as analyzer crystals. X-ray diffraction (XRD) was performed in order to determine the main crystal phases present in samples by means of a Bruker D8 Advance Diffractometer with CuK $\alpha$ radiation, with $2 \theta$ from $5^{\circ}$ to $85^{\circ}$, at a scan rate $2 \theta$ of $0.02^{\circ}, 5$ s per step. Tube setting was $40 \mathrm{kV}$ and $30 \mathrm{~mA}$. Aluminum nitride content in hazardous wastes was analyzed by Kjeldhal method using an automatic steam distilling unit UDK 130 A by Velp Scientifica, and subsequent titration with $1 \mathrm{M} \mathrm{HCl}$. The content of metallic aluminum was determined by treating samples with a $10 \% \mathrm{HCl}$ solution to solve aluminum acid soluble compounds. Filtrate was analyzed by atomic absorption spectrometry (AAS) in a Varian Spectra model AA-220FS equipment. 


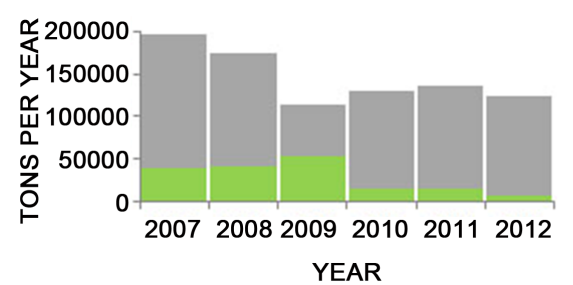

100304

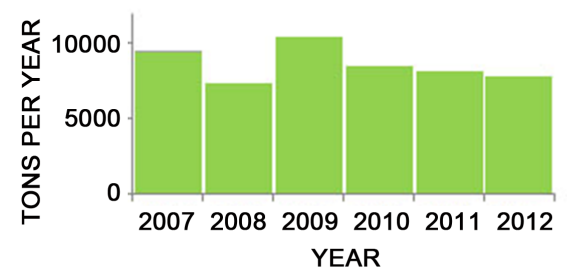

100309
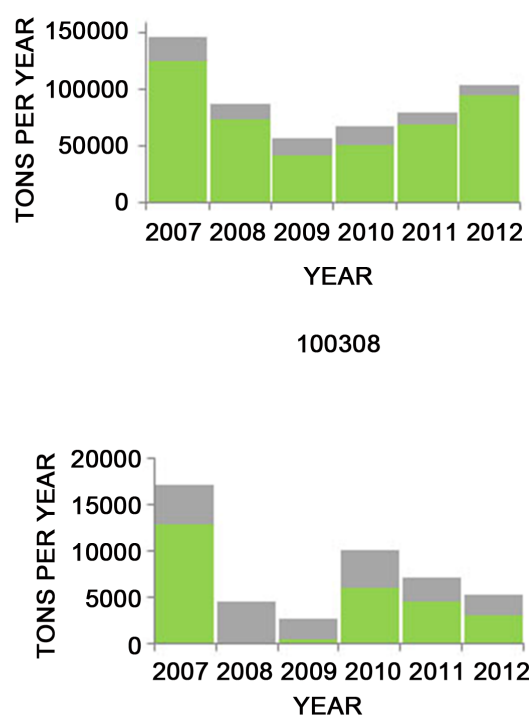

100321

Figure 3. Amount of hazardous waste (100304: primary smelting slag; 100308: secondary smelting salt slag; 100309: secondary smelting black dross; 100321: particulates and dust, including ball mill dust) transferred in the Spanish aluminum industry (statistical data compiled from [13]).

\section{Results and Discussion}

The particle size distribution for all investigated samples is shown in Table 2. As can be seen, samples present a high percentage of fine particles. Cumulative size distributions calculated at $50 \%\left(\mathrm{x}_{50}\right)$ indicate particle diameters less than $30 \mu \mathrm{m}$ for most of the samples, except for S5. These small size samples allow that fraction of particles can be inhalated by humans or penetrate into airways is relatively high as the cumulative distribution indicates at $10 \%\left(\mathrm{x}_{10}\right)$ [14]. Thus, it is observed that diameter sizes are around $2.5 \mu \mathrm{m}$ in most cases, except for S5 sample which contains larger particle size not only for $\mathrm{x}_{10}$ but also for all fractions. It is noticeable that the sample S11 exhibits the highest $\mathrm{x}_{90}$ value but numbers for $\mathrm{x}_{10}$ and $\mathrm{x}_{50}$ are very low. Furthermore, no significant differences have been found when different plans locations are compared. In general, samples consisted of very fine grain size which contributes to their hazardousness but also to their workability and handling properties. The distribution of particle size, determined by laser diffraction, showed for the most of wastes a trimodal tendency. Several examples of the distribution density curves are collected in Figure 4. Nevertheless, the sample S11 showed a quite different curve with a multimodal profile where peaks corresponding to small, medium and large size are appeared within a small range of distribution density, moreover, as above commented, this sample is the responsible for the grain size maximum value $(164.0 \mu \mathrm{m})$ of Table 2.

Concerning chemical composition, results from FRX are collected in Table 3 along with their statistical values: average value $(\bar{x})$ and standard deviation $(\sigma)$. The major component ranging between $53 \mathrm{wt} \%$ - $81 \mathrm{wt} \%$ corresponds to aluminum compounds which are expressed as $\mathrm{Al}_{2} \mathrm{O}_{3}$. Percentages lower than $10 \mathrm{wt} \%$ are obtained for other components, except for S5 where the highest contents of silica and sodium are found. Its high sodium content is attributable to the employ of high amounts of salt in the melting process to get a higher aluminum recovery; indeed, the $\mathrm{Al}_{2} \mathrm{O}_{3}$ content is the lowest one in this sample. The high percentage of $\mathrm{TiO}_{2}(>5 \mathrm{wt} \%)$ in samples S4 and S6 is noticeable and it may be associated with the different kinds of scrap used in secondary industry, and similarly, other metals (Fe, $\mathrm{Cr}$, etc.). The more efficiency achieved in the scrap classification prior to melting process the lower the content of those metals in the waste. Minor metals such as copper, zirconium, manganese, lead, and chromium are grouped in column "others". The high values obtained for the standard deviation of the average composition reveal the high variability of the chemical composition of samples. The main environmental problem related to these wastes, come from the contents of aluminum nitride and metallic aluminum (also aluminum carbide). Their high reactivity with water or even humidity in air, leads to formation of toxic and explosive gases such as ammonia, hydrogen and methane [2]. Table 4 shows the contents of alumi- 
Table 2. Particle size distribution of aluminum solid wastes from the bag filter suction systems used in the aluminum slag milling and statistical values $(\bar{x}, \sigma)$.

\begin{tabular}{cccc}
\hline & & Maximum particle diameter $(\mu \mathrm{m})$ & $x_{90}$ \\
\cline { 2 - 4 } Sample & $x_{10}$ & $x_{50}$ & 81.1 \\
S1 & 2.4 & 29.0 & 81.9 \\
S2 & 2.1 & 17.8 & 40.4 \\
S3 & 0.9 & 5.1 & 43.7 \\
S4 & 1.0 & 6.0 & 154.7 \\
S5 & 7.1 & 47.4 & 119.0 \\
S6 & 2.2 & 28.0 & 80.7 \\
S7 & 3.2 & 27.4 & 99.7 \\
S8 & 2.4 & 25.9 & 89.9 \\
S9 & 2.3 & 27.9 & 65.8 \\
S10 & 2.3 & 17.3 & 164.0 \\
S11 & 1.5 & 18.6 & 92.8 \\
$\bar{x}$ & 2.5 & 22.8 & 39.9 \\
\hline
\end{tabular}

Table 3. Waste composition (main components) obtained by XRF and expressed as oxides (wt\%).

\begin{tabular}{|c|c|c|c|c|c|c|c|c|c|c|}
\hline \multirow{2}{*}{ Sample } & \multicolumn{10}{|c|}{ XRF } \\
\hline & $\mathrm{Al}_{2} \mathrm{O}_{3}$ & $\mathrm{MgO}$ & $\mathrm{Fe}_{2} \mathrm{O}_{3}$ & $\mathrm{TiO}_{2}$ & $\mathrm{SiO}_{2}$ & $\mathrm{CaO}$ & $\mathrm{K}_{2} \mathrm{O}$ & $\mathrm{Na}_{2} \mathrm{O}$ & $\mathrm{Cl}$ & Others \\
\hline $\mathrm{S} 1$ & 79.3 & 4.7 & 0.6 & 2.7 & 2.9 & 2.2 & 1.0 & 2.5 & 2.0 & 2.3 \\
\hline S2 & 79.6 & 4.3 & 0.7 & 3.5 & 2.8 & 2.2 & 0.2 & 1.8 & 0.7 & 4.1 \\
\hline S3 & 80.9 & 3.4 & 0.7 & 3.4 & 2.7 & 2.1 & 0.3 & 1.7 & 0.9 & 4.0 \\
\hline S4 & 71.6 & 4.5 & 1.9 & 5.6 & 6.2 & 6.0 & 0.3 & - & - & 4.1 \\
\hline S5 & 53.4 & 6.8 & 1.2 & 0.5 & 17.8 & 2.9 & 1.1 & 10.5 & 3.5 & 2.4 \\
\hline S6 & 80.5 & 1.3 & 0.9 & 8.3 & 2.9 & 1.6 & 3.0 & 0.43 & - & 1.0 \\
\hline S7 & 77.9 & 3.8 & 1.3 & 0.4 & 7.6 & 2.5 & 1.1 & 2.81 & 0.9 & 1.7 \\
\hline S8 & 76.7 & 4.3 & 3.4 & 2.0 & 5.2 & 3.5 & 0.7 & 1.0 & 0.8 & 2.5 \\
\hline S9 & 76.9 & 4.1 & 0.4 & 3.2 & 2.6 & 2.0 & 0.6 & 3.2 & 3.4 & 3.7 \\
\hline S10 & 81.0 & 4.2 & 0.7 & 1.1 & 3.9 & 3.8 & 0.4 & 0.3 & - & 4.6 \\
\hline S11 & 71.2 & 4.3 & 1.8 & 1.5 & 10.6 & 2.9 & 0.6 & 1.7 & 1.5 & 4.1 \\
\hline $\bar{x}$ & 75.0 & 4.0 & 1.4 & 2.8 & 6.3 & 2.8 & 0.7 & 2.2 & 1.2 & 3.3 \\
\hline$\sigma$ & 8.0 & 1.2 & 1.0 & 2.3 & 4.7 & 1.1 & 0.7 & 2.7 & 1.2 & 1.3 \\
\hline
\end{tabular}

Table 4. Contents of aluminum nitride (AlN) (wt\%) and metallic aluminum ( $\left.\mathrm{Al}_{\mathrm{M}}\right)(\mathrm{wt} \%)$.

\begin{tabular}{cccccccccccccc}
\hline Sample & $\mathrm{S} 1$ & $\mathrm{~S} 2$ & $\mathrm{~S} 3$ & $\mathrm{~S} 4$ & $\mathrm{~S} 5$ & $\mathrm{~S} 6$ & $\mathrm{~S} 7$ & $\mathrm{~S} 8$ & $\mathrm{~S} 9$ & $\mathrm{~S} 10$ & $\mathrm{~S} 11$ & $\bar{x}$ & $\sigma$ \\
\hline $\mathrm{AlN}$ & 11.8 & 15.3 & 13.7 & 13.7 & 1.40 & 23.6 & 12.6 & 12.7 & 16.0 & 19.7 & 9.8 & 13.3 & 5.4 \\
$\mathrm{Al}_{\mathrm{M}}$ & 15.6 & 7.7 & 17.6 & 5.4 & 17.4 & 7.4 & 11.9 & 7.4 & 8.7 & 1.2 & 29.6 & 11.8 & 7.5 \\
\hline
\end{tabular}



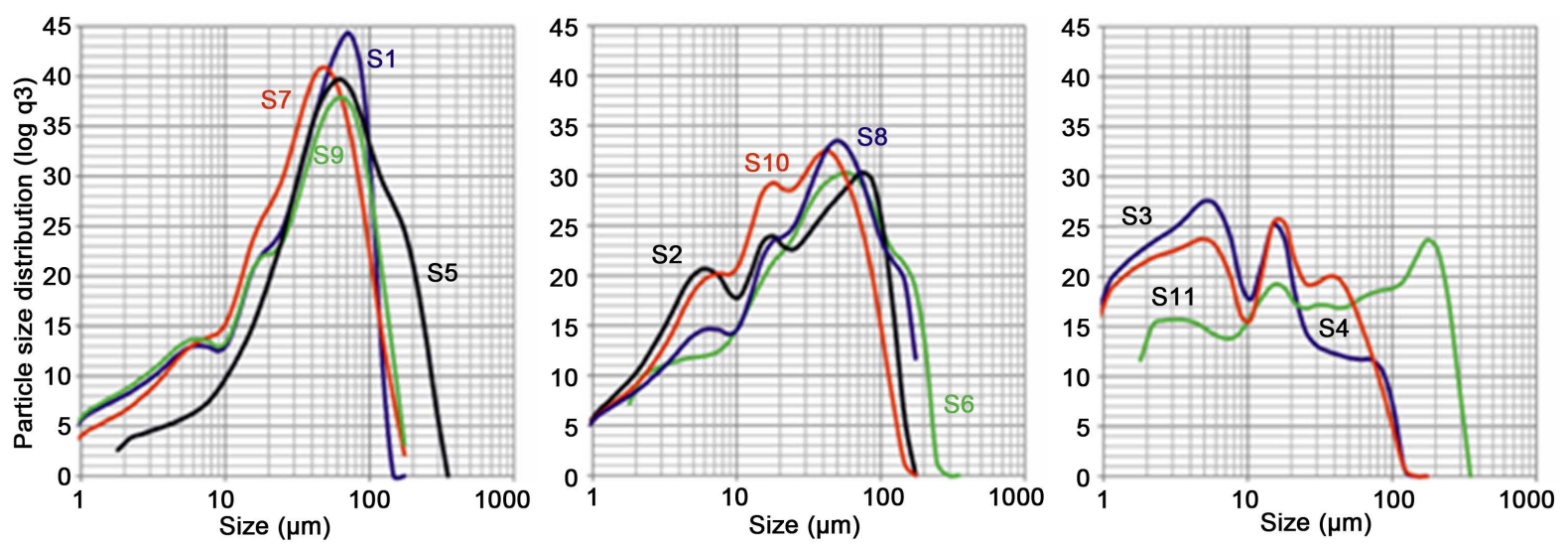

Figure 4. Particle size distribution curves of aluminum wastes.

num nitride (calculated from the results of the determination of ammonia by Kjendhal method) and metallic aluminum in the wastes. A high variability in results is observed as showed by the high value of standard deviation for both parameters. Concerning AlN, the lowest value (1.4 wt\%) is observed for S5 which is the sample with the highest content of salts and silica; and the highest value (23.6 wt\%) corresponds to S6. Gil in his study about Spanish slags in the secondary industry pointed contents in Aluminum Nitride lower than 5\% [15]. In this study, authors report higher contents of this compound in samples collected from tertiary industries in which slag is milled and the finest fraction is enriched in aluminum nitride and salts. Related to metallic aluminum contents, the highest value is obtained for S11. This sample also exhibits the highest $\mathrm{x}_{90}$ value which could be attributable to its highest metallic aluminum content, because of its spherical particles hardly crushed in the milling process in comparison with oxidized phases and salts.

From the aluminum nitride contents, the volume of ammonia gas, which can be generated by the wastes in presence of humidity, can be calculated by the reaction (1) [16]. Values range between $8-129 \mathrm{Nm}^{3}$ per ton of waste as can be seen in the Figure 5.

$$
\begin{gathered}
2 \mathrm{AlN}+3 \mathrm{H}_{2} \mathrm{O}(\mathrm{l}) \rightarrow 2 \mathrm{NH}_{3}(\mathrm{~g})+\mathrm{Al}_{2} \mathrm{O}_{3} \\
\Delta G_{0}{ }^{25^{\circ} \mathrm{C}}=-78.7 \mathrm{kcal}
\end{gathered}
$$

From the metallic aluminum contents, the volume of hydrogen evolved per ton of waste range between 14 $368 \mathrm{Nm}^{3}$ as shown in the reaction (2) [15] (Figure 5).

$$
\begin{aligned}
2 \mathrm{Al}+3 \mathrm{H}_{2} \mathrm{O}(\mathrm{l}) & \rightarrow 3 \mathrm{H}_{2}(\mathrm{~g})+\mathrm{Al}_{2} \mathrm{O}_{3} \\
\Delta G_{0}^{25^{\circ} \mathrm{C}} & =-208.0 \mathrm{kcal}
\end{aligned}
$$

From the mineralogical point of view, wastes comprise a mixture of both amorphous and crystalline phases as observed in the complex X-ray diffraction patterns (Figure 6). The crystalline phases mainly consist of not-well defined peaks with variable intensity. They are assigned to corundum, aluminum nitride, metallic aluminum and spinel (aluminum phases), along with other phases as quartz, calcium carbonate and $\mathrm{Na} / \mathrm{K}$ chloride. The ratio of these phases in the different samples is variable as a result of different factors such as scrap composition and the thermal treatment of slag, resulting in a high heterogeneity of the chemical composition of samples [2] [17]. The presence of high contents of salts in slag promotes the formation of a great number of tiny disordered phases in wastes, being S3 and S4 samples, those which present the most formation of this non-crystalline component. In this sense, peaks of sodium chloride (halite) with strong intensity are clearly observed in particular for all samples, except for S6 sample. Crystalline phases are mainly composed of not well defined peaks with variable intensities assigned to aluminum nitride, corundum and spinel. Quartz and calcium carbonate show low intensities. The specific thermal treatments received by the slag and the salt content explain differences between samples. Thus, slag produced at higher temperatures present their corundum and spinel phases with a better growth, as seen in S1, S2, S5 and S11. Peaks of iron oxide could not be unambiguously assigned and for samples with high content of $\mathrm{TiO}_{2}$, peaks corresponding to this compound were also poorly detected. The high background of all 


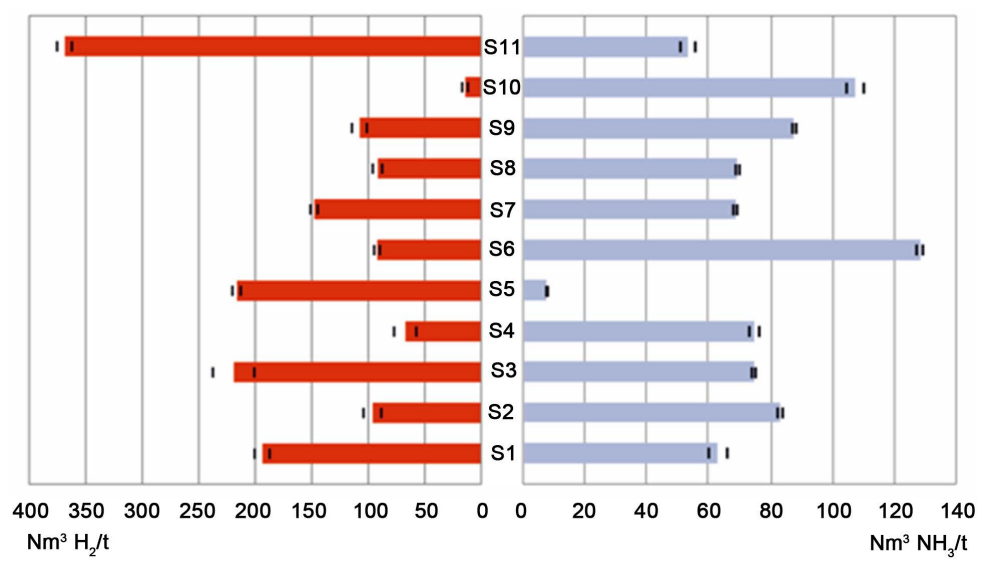

Figure 5. Ammonia and Hydrogen released by samples in presence of humidity, expressed in $\mathrm{Nm}^{3}$ per ton of waste. (| |, indicates the standards deviations of measurements).

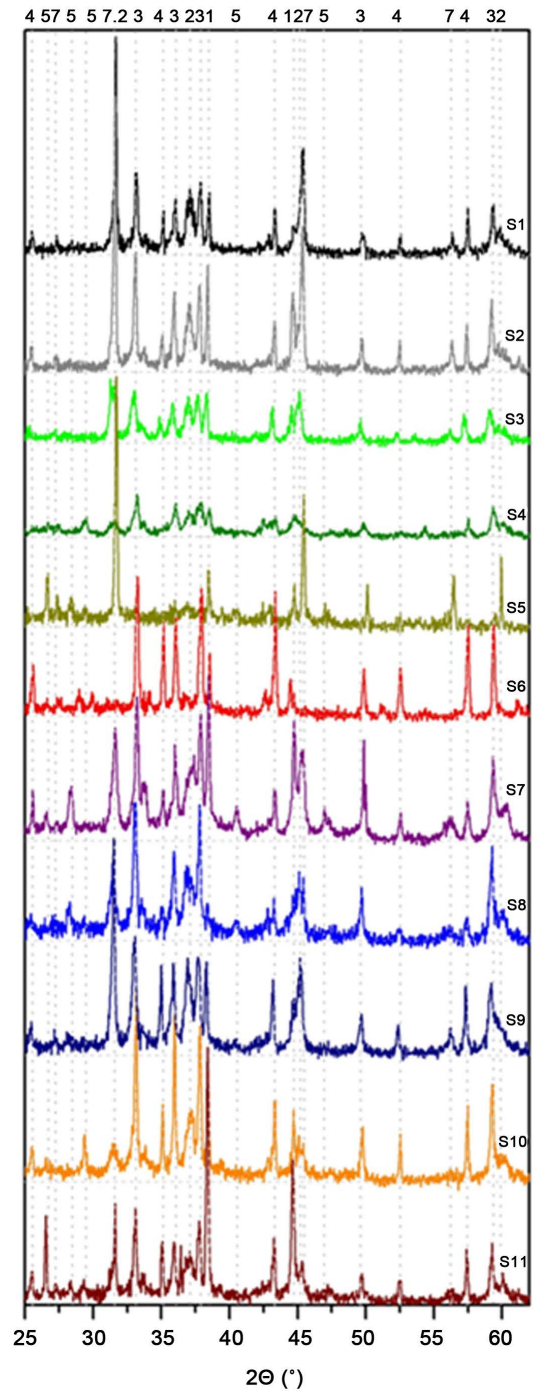

Figure 6. X-ray diffraction patterns of aluminum waste samples $(1=\mathrm{Al}$, aluminum; 2 = $\mathrm{MgAl}_{2} \mathrm{O}_{4}$, spinel; $3=\mathrm{AlN}$, aluminium nitride; $4=\mathrm{Al}_{2} \mathrm{O}_{3}$, corundum; $5=\mathrm{SiO}_{2}$, quartz; $6=$ $\mathrm{CaCO}_{3}$, calcium carbonate; $7=\mathrm{NaCl}$, halite). 
XRD patterns may inform about the existence of very low crystalline or amorphous compounds. On the other hand, no significant differences in composition have been observed when different locations were studied.

\section{Conclusion}

Hazardous wastes from Spanish tertiary aluminum industry were characterized. Wastes consisted of a heterogeneous blend of crystalline and non-crystalline phases, whose distribution depends on the thermal treatment of the slag, the saline content added during remelting process to recover the highest amount of aluminum, and the scrap composition from the secondary industry. In general, the content of aluminum (as oxide) represents more than $75 \%$ in weight, but the participation on it of aluminum nitride, metallic aluminum and corundum is very variable. The particle size of these wastes is relatively small, since $50 \%$ of grains are smaller than $30 \mu \mathrm{m}$ of diameter. By their composition, these wastes could not be landfilled. Relatively high amounts of toxic gases (ammonia and hydrogen) can be evolved to atmosphere. Others processes that convert the nitride and aluminum metal content of these residues into value-added products are necessary for the profitability of this recycling sector.

\section{Acknowledgements}

Authors thank the MINECO (Spain) for financing the project CTM2012-34449 and aluminum tertiary companies for supplying the wastes. R. Sánchez-Hernández thanks MINECO for the grant BES-2013-066269.

\section{References}

[1] Sevigné-Itoiz, E., Gasol, C.M., Rieradevall, J. and Gabarrell, X. (2014) Environmental Consequences of Recycling Aluminum Old Scrap in a Global Marked. Resources Conservation and Recycling, 89, 94-103. http://dx.doi.org/10.1016/j.resconrec.2014.05.002

[2] Tsakiridis, P.E. (2012) Aluminium Salt Slag Characterization and Utilization-A Review. Journal of Hazardous Materials, 217-218, 1-10. http://dx.doi.org/10.1016/j.jhazmat.2012.03.052

[3] Das, B.R., Dash, B., Tripathy, B.C., Bhattacharya, I.N. and Das, S.C. (2007) Production of $\eta$-Alumina Form Waste Aluminium Dross. Minerals Engineering, 20, 252-258. http://dx.doi.org/10.1016/j.mineng.2006.09.002

[4] López-Delgado, A. and Tayibi, H. (2012) Can Hazardous Waste Become a Raw Material? The Case Study of an Aluminum Residue: A Review. Waste Management and Research, 30, 474-484. http://dx.doi.org/10.1177/0734242X11422931

[5] Krnel, K., Drazic, G. and Kosmac, T. (2004) Degradation of AlN Powder in Aqueous Environments. Journal of Materials Research, 19, 1157-1163. http://dx.doi.org/10.1557/JMR.2004.0150

[6] López, F.A., Medina, J., Gutierrez, A., Tayibi, H., Peña, C. and López-Delgado, A. (2004) Treatment of Aluminium Dust by Aqueous Dissolution. Revista de Metalurgia, 40, 389-394. http://dx.doi.org/10.3989/revmetalm.2004.v40.i5.294

[7] Shinzato, M.C. and Hypolito, R. (2005) Solid Waste of Aluminium Recycling Process: Characterization and Reuse of Its Valuable Constituents. Waste Management, 25, 37-46. http://dx.doi.org/10.1016/j.wasman.2004.08.005

[8] Gonzalo-Delgado, L., López-Delgado, A., López, F.A., Alguacil, F.J. and López-Andrés, S. (2011) Recycling of Hazardous Waste from Tertiary Aluminium Industry in a Value-Added Material. Waste Management and Research, 29, 127-134. http://dx.doi.org/10.1177/0734242X10378330

[9] Renda, A., Pelkmans, J., Egenhofer, C., Marcu, A., Schrefler, L., Luchetta, G., Simonelli, F., Genoese, F., Valiante, D., Mustilli, F., Colantoni, L., Infelise, F., Stoefs, W., Teusch, J., Timini, J., Wieczorkiewicz, J., Zavatta, R., Giannotti, E. and Stecchi, G.M. (2013) Assessment of Cumulative Cost Impact for the Steel and the Aluminium Industry-Final Report Aluminium. Centre of European Policy Studies, Brussels.

[10] Observatorio Industrial del Metal (2010) El sector del reciclaje de metales en España. Ministry of Industry, Energy and Tourism, Madrid.

[11] Joint Research Center (2014) Best Available Techniques (BAT) Reference Document for the Non-Ferrous Metal Industries. Institute for Prospective Technological Studies Sustainable Production and Consumption Unit European IPPC Bureau. European Commission Final Draft, 496-505.

[12] ORDEN MAM/304/2002, de 8 de febrero, por la que se publican las operaciones de valorización y eliminación de residuos y la lista europea de residuos. In: BOE num. 43, de 19 de febrero de 2002, 6494-6515. http://www.boe.es/diario boe/txt.php?id=BOE-A-2002-3285 
[13] PRTR-España (2012) Ministry of Agriculture, Food and Environment, Madrid. http://www.en.prtr-es.es

[14] Marshall, J. (2013) PM 2.5. Proceedings of the National Academy of Sciences of the United States of America, PNAS, 110, 8756. http://dx.doi.org/10.1073/pnas.1307735110

[15] Gil, A. (2005) Management of the Salt Cake from Secondary Aluminum Fusion Processes. Industrial and Engineering Chemistry Research, 44, 8852-8857. http://dx.doi.org/10.1021/ie0508350

[16] López, F.A., Peña, M.C. and López-Delgado, A. (2001) Hydrolysis and Heat Treatment of Aluminum Dust. Journal Air \& Waste Management Association, 51, 903-912. http://dx.doi.org/10.1080/10473289.2001.10464314

[17] Huang, X-L., El Badawy, A., Arambewela, M., Ford, R., Barlaz, M. and Tolaymat, T. (2014) Characterization of Salt Cake from Secondary Aluminum Product Ion. Journal of Hazardous Materials, 273, 192-199.

http://dx.doi.org/10.1016/j.jhazmat.2014.02.035 